PLANNING PUBLIC SPENDING

IN THE UK 
Other books by Grahame Walshe

International Monetary Reform

Mergers and Concentration in British Industry

(with P. E. Hart and M. A. Utton)

Recent Trends in Monopoly in Great Britain 


\section{PLANNING PUBLIC SPENDING IN THE UK}

Grahame Walshe

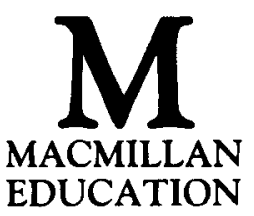


All rights reserved. No reproduction, copy or transmission of this publication may be made without written permission.

No paragraph of this publication may be reproduced, copied or transmitted save with written permission or in accordance with the provisions of the Copyright Act 1956 (as amended), or under the terms of any licence permitting limited copying issued by the Copyright Licensing Agency, 33-4 Alfred Place, London WC1E 7DP.

Any person who does any unauthorised act in relation to this publication may be liable to criminal prosecution and civil claims for damages.

First published 1987

Published by

MACMILLAN EDUCATION LTD

Houndmills, Basingstoke, Hampshire RG21 2XS

and London

Companies and representatives

throughout the world

British Library Cataloguing in Publication Data

Walshe, Grahame

Planning public spending in the UK.

1. Finance, Public-Great Britain

I. Title

$336.4 \quad \mathrm{HJ} 1001$

ISBN 978-0-333-44373-6

ISBN 978-1-349-18606-8 (eBook)

DOI 10.1007/978-1-349-18606-8 
To John 


\section{Contents}

List of Tables and Figures

Preface

viii

Acknowledgements

$\mathbf{x}$

$\mathrm{xi}$

Introduction: The Importance of Public Expenditure

1 From Plowden to Cash Planning

2 The Public Expenditure Planning Process

3 Public Spending Documentation

4 The Role of the Treasury

5 Resource Planning

6 The Advent of Cash Planning

7 A Perspective on Cash Planning

In Conclusion: The Future

Annex 1: The Definition of Public Expenditure 


\section{List of Tables and Figures}

\section{Tables}

3.1 1986 Autumn Statement on public expenditure 24

3.2 Public spending in cash terms by departments 26

3.3 Public spending in real terms by departments 27

3.4 1985/86: a sequence of sources for the planning total

4.1 Percentage changes in departmental spending between 1978/79 and 1985/86 (real terms)

5.1 Possible use of resources 1967/72 (basic case) 52

5.2 The growth and use of resources 1974-79 54

5.3 Real resources available for public expenditure 1983/88

6.1 The Medium Term Financial Strategy: projections and outturns

7.1 Public expenditure plans and outturns

7.2 The planning total in PEWP real terms $1981 / 82$ to 1986/87

$\begin{array}{lll}7.3 & \text { A comparison between deflators } & 77\end{array}$

$\begin{array}{lll}7.4 & \text { The planning total in real terms } & 78\end{array}$

7.5 A constellation of GDP-related objectives $\quad 79$

A.1 Measures of public spending (in cash) 90

A.2 Measures of public spending (in real terms) 90

A.3 Definitions of debt interest payments (cash) 91

A.4 Measures of public expenditure as a percentage of GDP

A.5 The link between the three definitions of public expenditure

A.6 The financing of general government expenditure 


\section{Figures}

3.1 Relationship between public spending plans and the supply estimates for $1986 / 87$

4.1 Panel A: stylised budget allocations, unadjusted optimality

Panel B: stylised budget allocations, adjusted optimality 


\section{Preface}

Books on public expenditure have a forbidding image. They are often written from an unacceptably partisan viewpoint; or weighed down by theoretical considerations; or remote from the institutional setting; or are highly condensed official presentations. But public spending is not the arcane subject those limitations define it to be. So in this book I have tried to reach beyond the small group of people in the City, Parliament and research institutions who make up the usual audience for material on public expenditure. My aim was to make the subject more accessible and stimulating to students of public finance and administration. I have sought to be as brief as possible; the political dimension is largely omitted; and I have attempted to simplify the theory required to give the facts their proper resonance. Four people, besides my editor Jennifer Pegg, have helped me: Anthea West, a tireless searcher after solecism; Sharon Wood, who patiently processed the typescript; David Miner, who taught me a bit about money; and David Heald, who made helpful comments on a draft. I am very grateful for their labour on my behalf. 


\section{Acknowledgements}

The authors and publishers wish to thank the following who have kindly given permission for the use of copyright material:

Basil Blackwell Ltd for material from 'Public expenditure on the social services: the economic and political constraints' by G. Davies and D. Piachaud from The Future of Welfare, ed. R. Klein and M. O'Higgins, 1985.

The Controller of Her Majesty's Stationery Office for Crown copyright material.

Every effort has been made to trace all the copy-right holders, but if any have been inadvertently overlooked the publishers will be pleased to make the necessary arrangement at the first opportunity. 